\title{
Constructing Student's Mathematical Understanding Skills and Self Confidence: Math Game with Visual Basic Application for Microsoft Excel in Learning Phytagoras at Junior High School
}

\author{
Martin Bernard*, Eva Dwi Minarti, Masta Hutajulu \\ Mathematics Education, IKIP Siliwangi, Cimahi, Indonesia \\ *Corresponding author E-mail: pamartin23rnard@gmail.com
}

\begin{abstract}
Learning media in Mathematics by using Microsoft Excel software that assisted Visual Basic application is a tool that can be applied for a more interactive visualization so that students better understand about mathematical concepts. Microsoft Excel is a software that serves to process data in the form of numbers that are always associated with mathematical commands. In addition, the functions of commands in Microsoft Excel can be applied in various fields such as Statistics, Economics and Finance, Mathematical Logic, and Engineering. If using mathematical concepts with data processing. But it is not just a number, it can also be used to process objects on shapes or drawings on images. This, of course, requires a function other than the mathematical functions of Visual Basic Applications, which can make math tools more interesting. The advantages of Microsoft Excel with Visual Basic for Application (VBA) are (1) the images are more interactive with different sizes and can make more; (2) more economical; (3)saving time; (4)the software is easy to find, and (5)improving students 'understanding of mathematical concepts and foster students' sense of trust, especially in junior high school students.
\end{abstract}

Keywords: VBA for Excel, Student Understanding, Math Game, Self Confidence

\section{Introduction}

Learning media in mathematics is a tool to illustrate students so that they can understand how to apply to various forms of problems related to mathematics. Mathematics is not a matter of numbers or mathematical symbols, but mathematics can help in solving problems when students can understand mathematics. In line with the goal of the media of mathematics is to deliver the success of students to master mathematical concepts [1]

Good media characteristics are media that can facilitate students' understanding ability, students find it difficult to learn mathematics initially, using the media students can be more skilled to solve problems [2]-[4]; in addition, good media can make students understand how to make the steps to get the right results; and subsequent good media characteristics, creating students for mathematics and being more active in problem-solving [5], [6]. In making the media need to consider the time and place conditions so that the media used more effective and meaningful for students.

Through the use of technology that many found one of them utilizing ICT[7], [8], is a consideration of effectiveness in the use of learning media[9]. With the existence of ICT, work becomes easier included in the field of mathematics education. The use of ICT has much to do with functions in mathematics, especially in mathematical logic. ICT is a medium that can improve teacher quality by creating a student-centered math learning atmosphere [10]. ICT is effective in learning math so it makes the job easier.

Through the use of technology that many found one of them utilizing ICT, is a consideration of effectiveness in the use of learning media. With the existence of ICT, work becomes easier included in the field of mathematics education. The use of ICT has much to do with functions in mathematics, especially in mathematical logic. ICT is a medium that can improve teacher quality by creating a student-centered math learning atmosphere [10]. ICT is effective to make learning math easier.

One of the most appropriate ICTs for the manufacture of mathematical media is Microsoft Excel because the software is rich in mathematical functions. In Microsoft Excel, the use of as a numerical processing developed its benefits in specific fields such as statistics, finance, engineering and mathematical logic. Commands in Microsoft Excel relate to math so as to facilitate the work included in mathematics education.

Microsoft Excel is a software that provides images of various sizes and shapes so that it can design according to the needs of props materials. In Microsoft, Excel images can be ordered to move so as to make the game more interesting [11]. The command to make objects or drawings in Microsoft Excel to be interactive is to write down the Visual Basic Application for Microsoft Excel code so that it can run the program and the results of objects or images that are static to be dynamic. So Microsoft Excel can be a software on learning tools mathematics.

The use of Visual Basic for Application (VBA) for Excel is actually very broad in mathematical learning such as creating variable equations and obtaining function results from variable equations [12], utilizing images with algebraic relationships such as finding Pythagoras theorem formulas ie adjusting the size of numbers for 
the sizes on the side- side of the triangle. In addition, VBA helps students find the information obtained to get the conclusion [13] The needs studied are junior high school students on how to improve students' comprehension and confidence in solving the Pythagoras problem. There are some that must be mastered by students is mastering the prerequisites or knowledge of mathematics on a basis that is primarily Euclid geometry. The students' understanding of geometry must be based on interesting instructions that make student development more significant [14].

Connecting geometry instructions using a computer will not stand alone from several sources but uniting the learning and teaching environment in the classroom [15]. The same thing about how students have not understood geometry because many concepts of geometric understanding have not yet integrated into the definitions or theories of geometry.

To determine the Pythagoras theorem, a design is made of relationships with right triangles [16]. Triangle images will be created in the image in Microsoft Excel and designed to prop using VBA for Microsoft Excel.

\section{Research Methods}

The research method is not based on quantitative measurements by judgment but with qualitative attempts to understand and interpret [17] based on the observed difficulty of high school students' ability and self-confidence questionnaires during initial mathematics learning before using VBA for Excel based games and end after using VBA for Excel based game. The study was conducted at a junior high school in one cimahi city with a class of 28 students.

\section{Results and Discussion}

The difficulty of the vocational students encountered while studying geometry is not yet able to understand mathematical symbols, operating numbers and identifying the right images. This constraint is because students have not mastered the basic concept or prerequisite mathematics well. Many of them, the work done is practical and fast, but as the process works, many students end up wrong.

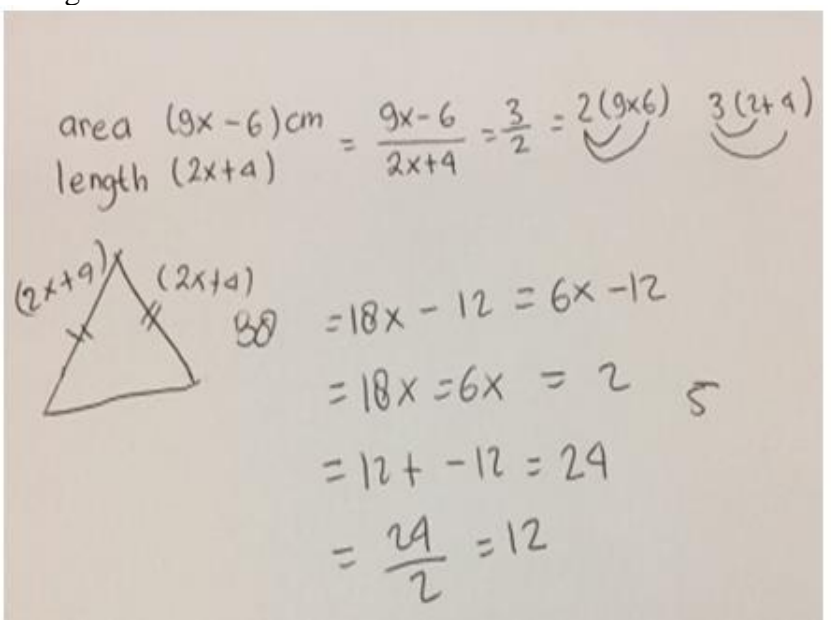

Fig 1: Student error on the first problem

In Figure 1 shows, that the first, the student of SMK has not been able to provide information about the initial step by writing the identity of the problem into a mathematical form. Secondly, the student has been able to perform the calculation process of comparative worth, but at the step of the calculation process, the students get difficulty to an understanding about the properties of counting operations such sum and multiplication. And third, the student is still incomplete giving the description of the triangle on the base.

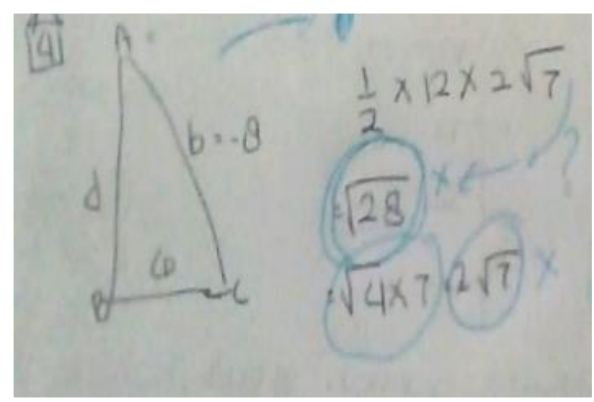

Fig 2: Student error for the second question

In Figure 2, it shows the error of number 2, the first student is correct about the result of the Pythagoras formula, but the multiplication process in search of the area of the triangle is still wrong and has not discovered yet, how the $2 \sqrt{ }(7)$ result obtained from the Pythagoras formula process. Secondly, students have been able to describe triangular shapes but have not yet understood the types of triangles, as illustrated that the student of a right triangular drawing figure does not include symbols of angles $90 \mathrm{o}$ or rightangled.

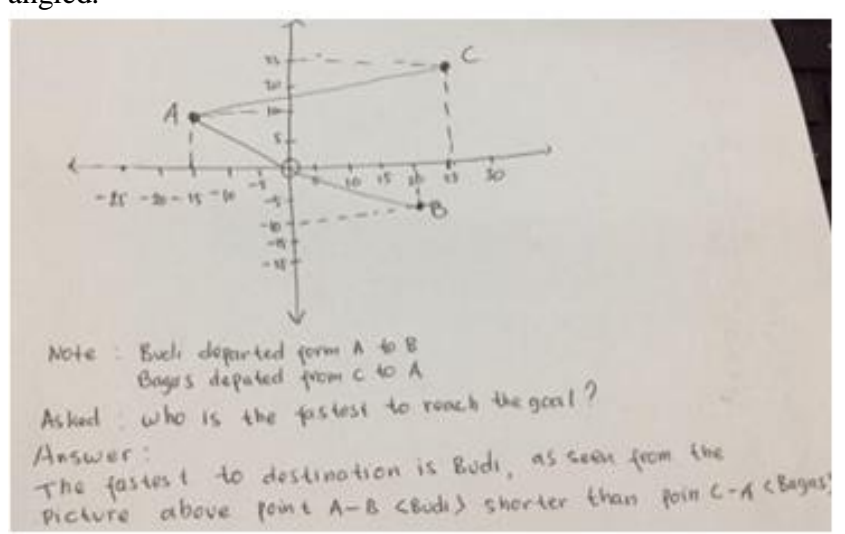

Fig 3: Student error for the third question

In Figure 3, it shows students' errors when determining the answer of which is faster when both people are in the same position at point $\mathrm{A}$. When the two people move in different directions, the first person moves to point $\mathrm{B}$ and second person to point $\mathrm{C}$ The students' answers do not show distance in the form of scalar value or scale but in the form of statement or guess, in this case the students have not understood the concept of Pythagoras theorem and Pythagoras application into everyday life.

Based on these three problems, it shows the obstacles of junior high school students, namely: first, the students have not been able to master about prerequisites such as comparison, number multiplication operations, one variable equation; secondly, students have not been able to relate the math of Pythagoras into everyday life; thirdly, students have not been able to link between images into the form of mathematical processes.

Table 1: Difficulties Of Junior High School Students About Phytagoras Materials

\begin{tabular}{|l|l|c|c|}
\hline No & \multicolumn{1}{|c|}{ Student Difficulties } & $\begin{array}{c}\text { Amount } \\
\text { Students }\end{array}$ & Presentation \\
\hline 1 & $\begin{array}{l}\text { Applying images in mathematical } \\
\text { concepts }\end{array}$ & 12 & $42,86 \%$ \\
\hline 2 & $\begin{array}{l}\text { Mastery of basic mathematical } \\
\text { prerequisites on definitions and } \\
\text { theorems }\end{array}$ & 26 & $92,8 \%$ \\
\hline 3 & $\begin{array}{l}\text { Making steps in the count } \\
\text { operation }\end{array}$ & 14 & $50 \%$ \\
\hline 4 & $\begin{array}{l}\text { Linking mathematical logic in the } \\
\text { process of counting }\end{array}$ & 16 & $57,14 \%$ \\
\hline
\end{tabular}


Based on the three factors that are the constraints of students to master the material Pythagoras, and solutions for learning objectives Pythagoras lesson material can be achieved, the first to create a strategy of learning media based on math games. The importance of the use of images associated with mathematics, viewed from the mastery of the material was the key to the weakness of students on the mastery of the basic mathematics requirements of definitions and theorems such as the understanding of line alignment, the distance of two points due to weak mastery of Pythagoras theorem, and less able to understand the properties of the process of counting addition and multiplication.

In general, students feel an objection, if the math is a routine and monotonous activities that make students bored to learn math. Basically that most students prefer games rather than having to learn math. Though mathematics is also a fun math. Therefore, teachers should create a medium of mathematics learning based on the constraints found in the classroom.

It is certainly not easy for a teacher to acquire and create mathematics learning media; this requires considerable consideration of material costs and time of manufacture. The solution is the creation of ICT-based props that are based on Visual Basic Application for Microsoft Excel or abbreviated as VBA for Excel. The use of Microsoft Excel is the first to provide images of various shapes and sizes tailored to the needs of utilizing the math function as a command running Shapes or images.

The first design, making mathematical tools prerequisite about fractions to understand the division of junior high school students. The comparison is made for the two fractions whose goal the student understands the movement of the denominator from the right to the multiplication to the left, as well as the denominator of the left segment, is moved to times on the right.

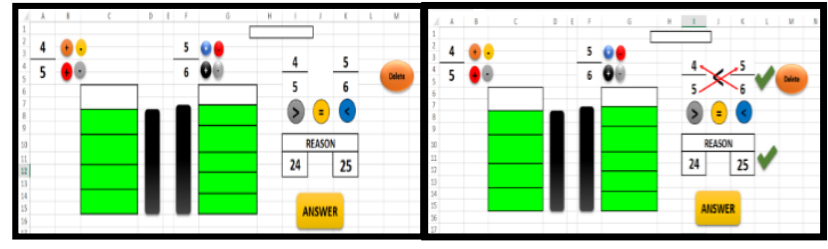

Fig 4: Understanding Media Design

Students will try from a few fractional comparisons and determine larger and smaller by using the reason for the answer, the goal students can understand the process of both comparisons. After creating the drawing design on sheet 1 , then entering the language of the VBA for Microsoft Excel program in relation to the fraction. While the coloring function of the new section is understanding how many students are filling in the glass it understands the student to declare the denominator on the fraction.

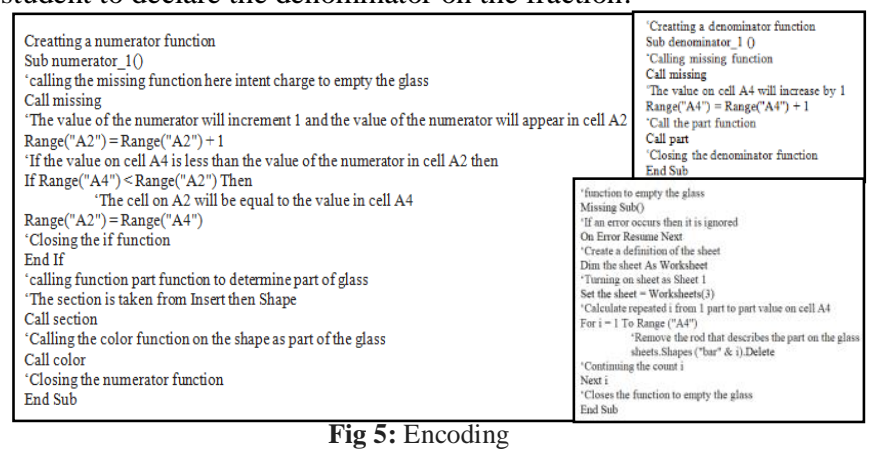

The above code specifies that the value or number for the numerator will be displayed on cell A2 and on the glass part will be given a green color while raising the shapes for the glass part depends on the value or number on cell A4 as the denominator.

The part function depends on the value of the function of denominator_1 and the numerator_1, which corresponds to the number or value of cells A2 and cell A4, at the beginning fractional, run on the part of the denominator_1 and will appear the shape of the part that divides the glass according to the division of values on cell
A4. After that give the shapes section. Likewise for the second glass in the same way on different cells. To design that VBA for Excel to disappear, the parts and colors associated with denominators and numerators.

The second function serves to describe the part of the glass by using a customized Shapes cell on a Sheet in Microsoft Excel so that students understand the concept of fractional numbers.

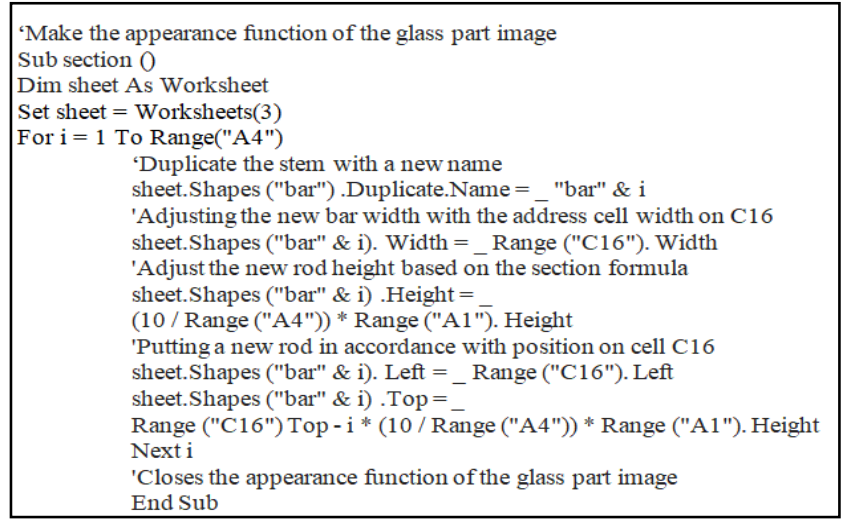

Fig 6: Encoding

The coloring function of the new stem is to understand the students how many sections are filled with the glass this understands the student to declare the denominator on the rupture.

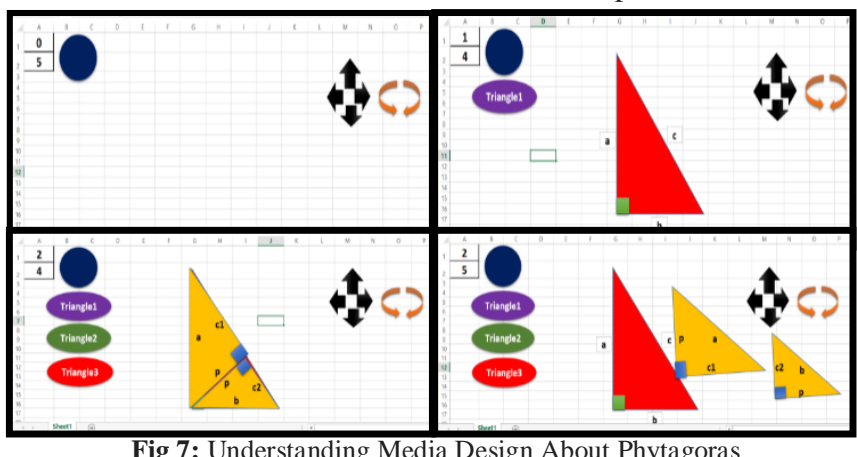

Figure 7 shows, there is a connection fraction with Pythagoras theorem, the students already understand the comparative comparison of uniform, so students get the formula findings from Pythagoras. And the process way to find the formula as follows.

Known that $c=c_{1}+c_{2}$

The 1st triangle is similar to the big triangle (triangle before cutting)

$\frac{c_{1}}{a}=\frac{a}{c} \leftrightarrow c_{1}=\frac{a^{2}}{c}$

The second triangle is similar to the big triangle (triangle before cutting)

$\frac{c_{2}}{b}=\frac{b}{c} \leftrightarrow c_{2}=\frac{b^{2}}{c}$

Because of $c=c_{1}+c_{2}$ so

$c=\frac{a^{2}}{c}+\frac{b^{2}}{c} \leftrightarrow c^{2}=a^{2}+b^{2}$

In the making of the media, there are some very important language factors in introducing a right triangle, two pieces of a right triangle into different right-angled or triangular triangles, triangle from right to left, top to bottom and playback triangle, to make the three triangles illustrated each other congruence. And the main code of the triangle as follows: 


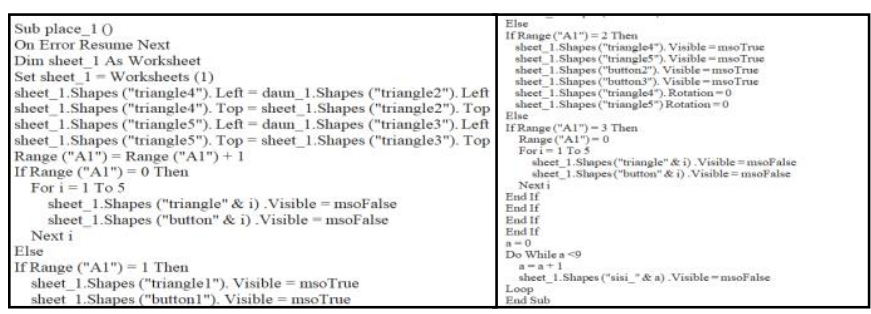

Fig 8: Encoding

The VBA code above shows the triangle stages of the right triangle shape before being cut into the form of 2 right triangle pieces and giving a description to the right triangle. From here students will find the basic formula of the Pythagoras theorem. After the students understand about Pythagoras, it relates the Pythagoras theorem to the distance between two points.

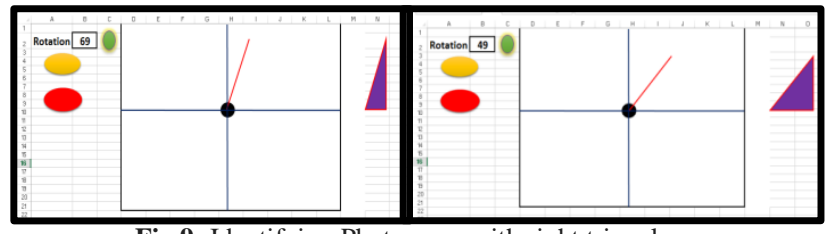

Fig 9: Identifying Phytagoras with right triangles

Figure 9. Showing the length of a line segment from two points and then attributed to an elbow triangle so that the students can easily identify the segment with the sides of a right triangle, consisting of the arrangement elements ie the front side relating to the $\mathrm{y}$-axis and the sides with the axis $\mathrm{x}$ and obtained the distance formula.

Distance $=\sqrt{(x-0)^{2}+(y-0)^{2}}=\sqrt{x^{2}+y^{2}}$

It can be concluded that a line segment formed from two points whose origin is not $(0,0)$ is changed to $\left(x_{1}, y_{1}\right)$, obtained, Distance $=\sqrt{\left(x-x_{1}\right)^{2}+\left(y-y_{1}\right)^{2}}$.

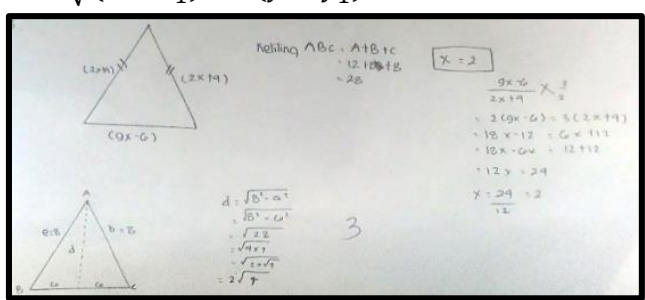

Fig 10: Students are able to work on Pythagoras

Figure 10. Showing that students have been able to work on and apply questions related to the Pythagoras theorem, by making appropriate steps. From the final result in the learning in the classroom, students' difficulties are obtained. This is similar to [18] said that students' reasoning ability that obtains software-assisted learning is better than students who get regular learning.

Table 2: Difficulties of Student In Junior High School About Phytagoras Materials

\begin{tabular}{|c|c|c|c|}
\hline No & Student Difficulties & Amount Students & Presentation \\
\hline 1 & $\begin{array}{l}\text { Applying images in } \\
\text { mathematical concepts }\end{array}$ & 3 & $10,71 \%$ \\
\hline 2 & $\begin{array}{l}\text { Mastery of basic } \\
\text { mathematical } \\
\text { prerequisites on } \\
\text { definitions and theorems }\end{array}$ & 2 & $7,14 \%$ \\
\hline 3 & $\begin{array}{l}\text { Making steps in the } \\
\text { count operation }\end{array}$ & 1 & $3,57 \%$ \\
\hline 4 & $\begin{array}{l}\text { Linking mathematical } \\
\text { logic in the process of } \\
\text { counting }\end{array}$ & 5 & $17,85 \%$ \\
\hline
\end{tabular}

Table 2 shows that students 'difficulties have been significantly reduced so that learning of mathematics games using Visual Basic
Application for Microsoft Excel is more effective for students' ability to understand high school. And it can be seen also Table 3 about student self-confidence questionnaire.

Table 3: Self-Confidence About Phytagoras Materials

\begin{tabular}{|c|c|c|c|}
\hline No & Student Difficulties & Amount Students & Presentation \\
\hline 1 & $\begin{array}{l}\text { Student independence in } \\
\text { working on the problem }\end{array}$ & 25 & $89,28 \%$ \\
\hline 2 & $\begin{array}{l}\text { Dare to solve math } \\
\text { problems }\end{array}$ & 22 & $78,57 \%$ \\
\hline 3 & $\begin{array}{l}\text { Dependence on the } \\
\text { teacher }\end{array}$ & 5 & $17,85 \%$ \\
\hline 4 & $\begin{array}{l}\text { Fear of making a } \\
\text { mistake }\end{array}$ & 8 & $28,57 \%$ \\
\hline 5 & $\begin{array}{l}\text { Easy to understand math } \\
\text { while using media }\end{array}$ & 26 & $92,85 \%$ \\
\hline 6 & $\begin{array}{l}\text { More enthusiasm to } \\
\text { learn when already } \\
\text { understand math }\end{array}$ & 24 & $85,71 \%$ \\
\hline
\end{tabular}

\section{Conclusion}

From the results of qualitative research that the increase of students to master the ability of understanding when the math learning using VBA-based math games for Microsoft Excel and the confidence of students more have a positive response. And the VBA-based math game for Microsoft Excel is an alternative to improving the understanding ability of junior high school students.

\section{Acknowledgement}

The study provides an eatable remark to the IKIP Siliwangi which has given place and time to do research.

\section{References}

[1] A. Buchori and R. D. Setyawati, "Development Learning Model of Charactereducation Through E-Comic In Elementary School,” Int. J. Educ. Res., vol. 3, no. 9, pp. 369-386, 2015

[2] M. Bernard, "Meningkatkan kemampuan komunikasi dan penalaran serta disposisi matematik siswa SMK dengan pendekatan kontekstual melalui game adobe flash cs 4.0," Infin. J., vol. 4, no. 2 , pp. 197-222, 2015 .

[3] J. Simarmata et al., "Prototype Application Multimedia Learning for Teaching Basic English,” Int. J. Eng. Technol., vol. 7, no. 2.12, pp. 264-266, Apr. 2018.

[4] N. Nasrudin, I. Agustina, A. Akrim, A. S. Ahmar, and R. Rahim, "Multimedia educational game approach for psychological conditional,” Int. J. Eng. Technol., vol. 7, no. 2.9, pp. 78-81, 2018.

[5] Suarjana, I. M., N. P. N. Riastini, and I. G. N. Y. Pustika, "PENERAPAN PENDEKATAN KONTEKSTUAL BERBANTUAN MEDIA KONKRET UNTUK MENINGKATKAN AKTIVITAS DAN HASIL BELAJAR," Int. J. Elem. Educ., vol. 1, no. 2, pp. 103-114, 2017

[6] E. Kartikadarma, T. Listyorini, and R. Rahim, "An Android mobile RC4 simulation for education," World Trans. Eng. Technol. Educ., vol. 16 , no. 1 , pp. 75-79, 2018.

[7] D. Napitupulu et al., "Analysis of Student Satisfaction Toward Quality of Service Facility,” J. Phys. Conf. Ser., vol. 954, no. 1, p. 012019, Jan. 2018.

[8] K. Adiyarta, D. Napitupulu, R. Rahim, D. Abdullah, and M. Setiawan, "Analysis of e-learning implementation readiness based on integrated elr model," J. Phys. Conf. Ser., vol. 1007, no. 1, p. 012041, Apr. 2018.

[9] S. Sriadhi, R. Rahim, and A. S. Ahmar, "RC4 Algorithm Visualization for Cryptography Education,” J. Phys. Conf. Ser., vol. 1028, no. 1, p. 012057, Jun. 2018.

S. Marshall, "eLearning and ICT in secondary and tertiary education,” Int. J. Educ. Dev. Using Inf. Commun. Technol., vol. 14, no. 1, pp. 2-3, 2018.

G. Singh and K. Siddiqui, "Microsoft Excel software usage for teaching science and engineering curriculum," J. Educ. Technol. Syst., vol. 37, no. 4, pp. 405-417, 2009. 
[12] S. E. Buttrey, "Calling the lp_solve linear program software from R, S-PLUS and Excel.," J. Stat. Softw., vol. 14, no. 4, pp. 1-13, 2005.

[13] Chotimah, S., Bernard, M. and S. M. Wulandari, "Contextual approach using VBA learning media to improve students' mathematical displacement and disposition ability.," vol. 948, no. 1, p. 12025, 2018.

[14] A. Duatepe-Paksu and B. Ubuz, "Effects of drama-based geometry instruction on student achievement, attitudes, and thinking levels.," J. Educ. Res., vol. 102, no. 4, pp. 272-286, 2009.

[15] B. Guven, "Using dynamic geometry software to improve eight grade students' understanding of transformation geometry.," Australas. J. Educ. Technol., vol. 28, no. 2, 2012.

[16] Heller, J., C. Steiner, C. Hockemeyer, and A. Dietrich, "Competence-based knowledge structures for personalised learning.," Int. J. ELearning., vol. 5, no. 1, p. 75, 2006.

[17] I. Gunawan, "Metode penelitian kualitatif," Jakarta Bumi Aksara, 2013.

[18] E. Senjayawati and M. Bernard, "PENERAPAN MODEL SEARCH-SOLVE-CREATE-SHARE UNTUK MENGEMBANGKAN KEMAMPUAN PENALARAN MATEMATIS BERBANTUAN SOFTWARE GEOGEBRA 4.4.," MAJU J. Ilm. Pendidik. Mat., vol. 5, no. 1, 2018. 